Excellence in Performing Arts Research

Volume 6

2019

\title{
Addressing Bisexuality, Gender Non Conformance and Performativity through The Color Purple by Alice Walker
}

Chantrell M Lewis

This paper won the Award for Excellence in Undergraduate Research, Honorable Mention, 2018-19.

\section{Citation Elements}

Lewis, Chantrell M (2019). Addressing Bisexuality, Gender Non Conformance and Performativity through The Color Purple by Alice Walker. Excellence in Performing Arts Research Vol. 6 Retrieved from https://oaks.kent.edu/epar/v ol6/iss1/addressing-bisexuality-gender-non-conformance-and-performativity-through-color 


\begin{abstract}
The purpose of this paper is to elaborate on the knowledge of bisexual relationships that occurred in the early 1900s regardless of the sexual and racial oppression of the time period. Though this paper is based off a novel/musical, it is considered historical fiction and much of the writing within the piece is truthful. I believe that through art and literature we are able to experience and view the human experience through a greater lens. The Color Purple, by Alice Walker and adapted for stage by Marsha Norman, walks us through the relationships our main character, Celie, is involved in and evolves through. During the story we see some women completely dismiss gender norms and shape their village as they see it fit. The audience sees many facets of her trauma and how her life events affected her attraction and affection towards certain relationships, but most importantly, the relationship she has with herself.
\end{abstract}

\title{
Paper
}

The Color Purple the Musical is based on a novel written by Alice Walker. The topics of sexual orientation and gender are crucial to a deeper understanding of this piece of literature. The Color Purple serves as a boundary-breaking work of art which proves bisexuality and gender non-conformance were alive and well despite the racial and sexual oppression of the time. The story follows the life of Celie, a woman born and raised in Georgia. At the age of 14, she is sent off to marry a man we know throughout the storyline as "Mister." As the plot develops, Celie meets a multitude of characters that play a crucial role in the development of her self-image, the world, and her place in it.

As a young girl, Celie's father sexually abused her. She had been impregnated twice by the age of 14. Both children were taken from her and given to other families. The sexual abuse she faced had significant physical and emotional impact on Celie's transition into womanhood. Her feelings about affection and sex were driven by her traumatic experiences. She was hesitant to trust men. This was demonstrated in the meekness in which she approaches her marriage to Mister. The relationship between Celie and Mister is possibly even more abusive than the relationship with her father. Mister assigns her to cook, clean, and raise his misbehaved children. Celie, with very few options, succumbs to this new lifestyle. Her lifetime passes over the course of the play. Celie and her sister Nettie are separated at the hand of Mister. We see the evolution of her family, cycles of abuse, and the resurfacing of a love thought to be lost. The story concludes in the homecoming of Celie's children, her sister Nettie, and the grand opening of a new clothing store where Celie sews pants for women.

We get the first glimpse of Celie's sexual interest as she is having a conversation with Shug Avery, a blues singer and Mister's ex-lover. Shug Avery is the daughter of the town's Reverend. She is a female version of the biblical prodigal son. To be black and a member of the LGBTQ community was considered taboo. To be the black, bisexual daughter of the Reverend was deemed punishable by execution. Black churches were some of the most influential organizations within their communities, shaping the way of life. There has been an ongoing war with homosexuality in black churches. A flaw within the church is the ever-present church gossip, which is highlighted in the first number of the show. Negativity surrounding the integration of gayness, blackness, and Christianity is one of the main causes of depression and mental degradation in youth and encourages secrecy, denial, and confusion. In order to escape these things, Shug left town. 
Upon her first encounter with Shug, Celie was met with the words "You sho is ugly" (52). As the women learn more about each other, Celie reveals to Shug that she finds herself very disinterested in sexual encounters with Mister. She states, "Most times I pretend I ain't even there. He never know the difference. Never ast me how I feel, nothing. Just do his business, get off, go to sleep" (Walker, 131). This is a clear indicator of the disconnect she feels from her husband. Each time Celie has had a sexual encounter, it has created a divide between Celie and her ability to uncover affection towards men.

Shug provides new attitudes to Celie's self-perspective. In the ballad "Too Beautiful for Words," Shug sings, "You hide your head under your wings, just like a little bird. Don't you know, you're beautiful, too beautiful for words?" This is a significant line as Shug states what is obvious to the audience but hidden from Celie: she hides herself. Shug then follows with a declaration of Celie's beauty in spite of this. Shug opened Celie's eyes to a non-toxic form of love that strengthens Celie's attraction to her. "Lord, I wants to go so bad. Not to dance. Not to drink. Not to play card. Not even to hear Shug Avery sing. I just be thankful to lay eyes on her" (Walker, 63). Though in the musical the sexual relationship between Shug and Celie is slightly censored, the connection is still very evident in the approach taken by the actresses. Text from the novel indicates that the two women make love.

While analyzing the text, it is important to address the behavior of our characters and the language of the time. In analyzing the verbal abuse Celie received from her father, we understand the origins of her lack of self-confidence. One of the beginning numbers, "Our Prayer," unveils her father's wickedness towards her. He states, "Well, next time you come you can look at her. She ugly. Don't even look like she kin to Nettie. But she'll make the better wife. She ain't smart either, and I'll just be fair, you have to watch her or she'll give away everything you own. But she can work like a man" (Walker, 41). This affects the way Celie carries herself. She grows comfortable in her masculinity, feeling as though it is all she has to offer. She is intrigued by feminine behavior, but never engages with her feminine side. She utilizes this ability as a tool for survival to maintain her durability. Mister tells her, "You black, you pore, you ugly, you a woman" (Walker, 289). These words were etched in her head throughout her marriage and set the tone for Celie's mindset. Mental health within marginalized communities has been viewed as insignificant. To the black community, survival has always taken precedence over peace. The damage to Celie's psychological intuition was immeasurable, making it a substantial part of her existence. It became mandatory for Celie to seek refuge in her disparity rather than hiding from it.

During her time with Mister, Celie meets Sophia, a woman who sees no divide between male and female behavioral qualities. Our playwright takes Sophia's character and allows her to become the embodiment of what all men could only have wished to be: tall, large, and in charge. Her role in the dismissal of gender norms within the piece is significant. In her very famous line from the musical, she states, "You told Harpo to beat me ... I'll kill him dead before I let him beat me" (Walker, 81). Sophia then explains to Celie that she has fought her husband and will do what is necessary to be respected and stay alive. Unlike Celie, Sophia knows that surviving and living are two different things. Harpo, Celie's son-in-law, was a non-gender conforming woman for the majority of his life. Harpo is now married to a woman who is also non-gender conforming. His attempt to make her conform results in her shattered pride and his black eye.

Celie's lack of a true family creates loneliness. She begins forming significant relationships with the women in her life and, regardless of her inability to break free from her marriage, she recreates her kin. Rather than blood, these women form a family bond connected 
by circumstance: Sophia, a motherly influential role, Shug as her lover, her sister Nettie, and God, who has, throughout the play, been her confidant. This is the family she chose.

Celie and Nettie's relationship begins as a praying one. They are children who play, run, dream, and pray to God to keep their souls together. Neither woman share dreams of becoming wives, but rather of being mothers and teachers. Their lives progress without each other. Nettie is unmarried, a world traveler and caring for Celie's two children in Africa while addressing gender politics and doing missionary work. She even mentions that the men of the Olinka tribe devalue her because she is not married, giving insight that sexual oppression and repression was spread through both Africa and the African diaspora at the time.

Once Celie courageously escapes her marriage, she opens a store where she sells pants. No skirts, no dresses. Just pants. Look who's wearin' the pants now. The Color Purple proves that to be a black, gay, Christian woman during the time meant to be ugly, an outcast, and alone. It has taken many years of growth and understanding within the black community to find a place where blackness and bisexuality can coexist. 


\section{Works Consulted}

Books, Alyson. The Greatest Taboo: Homosexuality in Black Communities 2001.

Clark, Anna. Alice Walker: The Official Website, https://alicewalkersgarden.com/books/bookthe-color-purple/. Accessed 10 Mar. 2019.

Douglas, Kelly. Reflections. Yale University. 2006, https://reflections.yale.edu/article/sex-andchurch/black-church-homophobia-what-do-about-it. Accessed 10 Mar. 2019.

Johnson, E. Patrick. Black. Queer. Southern. Women.: An Oral History 2018.

Mellowes, Marilyn. American Experience. PBS.

https://www.pbs.org/wgbh/americanexperience/features/godinamerica-black-church/. Accessed 10 Mar. 2019.

Walker, Alice. The Color Purple. Open Road Media. 2011. Ebook. 